RASĀYAN J. Chem.

Vol. 13 | No. 3 |1685-1691| July - September | 2020 ISSN: 0974-1496 | e-ISSN: 0976-0083 | CODEN: RJCABP

\title{
SYNTHESIS, SPECTRAL STUDY AND ANTIBACTERIAL ACTIVITY OF ASYMMETRICAL TETRADENTATE SCHIFF BASE COMPLEXES
}

\author{
U. Agarwal ${ }^{1}$, N.P. Singh ${ }^{2, *}$, A. Kumar ${ }^{1}$ and K. Kumar ${ }^{1}$ \\ ${ }^{1}$ Department of Chemistry, Meerut College, Meerut-250001 \\ (Affiliated to C.C.S. University), (U.P.) India \\ ${ }^{2}$ Department of Chemistry, DDU Gorakhpur University, Gorakhpur-273009, (U.P.) India \\ *E-mail: npsmcm.in@gmail.com
}

\begin{abstract}
The Ligand 3,3-((1E,1 E)-((4-methyl-1,2- phenylene)bis(azanylylidene))bis(methanylylidene))bis(naphthalene-2-ol) ( L) have been used to synthesize four new $\mathrm{Cr}(\mathrm{III}), \mathrm{Co}(\mathrm{II}), \mathrm{Zn}(\mathrm{II})$, and $\mathrm{Cd}(\mathrm{II})$ complexes(1-4). The Ligand (L) was derived from the condensation of 3,4- diamino Toluene and 2- hydroxy naphthaldehyde in 1:2 molar ratio. The ligand and four new metal complexes were characterized by Spectroscopic studies. Physical methods such as Melting points, Elemental Analysis, and Magnetic moment properties. The FT-IR spectral data indicate that the synthesized ligand was coordinated with the metal ion in a tetradentate manner. The UV/Visible spectra and magnetic moment data showed octahedral geometry for $\mathrm{Cr}$ (III) and $\mathrm{Co}$ (II) complexes whereas $\mathrm{Zn}$ (II) and $\mathrm{Cd}(\mathrm{II})$ showed distorted square pyramidal structure. The magnetic moment of metal complexes was low as expected. The synthesized metal complexes were insoluble in many organic solvents thus supports the proposed structure. The tetradentate Schiff base ligand and complexes (1-4) were tested against bacteria E. coli, B. megaterium and $P$. aeruginosa for their antibacterial activity for the determination of inhibition potential.

Keywords: Antibacterial Activity, Octahedral Geometry, Square Pyramidal Geometry, Schiff Base Complexes, Spectral Data.
\end{abstract}

(C) RASĀYAN. All rights reserved

\section{INTRODUCTION}

Many organic compounds containing naphthaldehyde moieties have been studied in coordination chemistry due to their facile synthesis, electronic properties and therapeutic treatments for diseases. ${ }^{1,2}$ The study of d block elements with aromatic Schiff bases have been focused as a result of their various biological activities, structural varieties, potential application, ${ }^{3}$ photochromic properties ${ }^{4-7}$ and synthetic applicabilities. ${ }^{8}$ Schiff bases are synthesized by the condensation of aldehyde/ ketone and primary amines in the presence of base or acid catalyst, resulting in the formation of azomethine $(-\mathrm{CH}=\mathrm{N}-)$ group. The heavy metal Schiff base complexes have been received increasing attention owing to their remarkable characteristics, biochemical, pharmacological properties ${ }^{9}$, biological activities ${ }^{10,11}$, catalytic activity ${ }^{12,13}$, antibacterial ${ }^{14-17}$, anticancer ${ }^{18-20}$, antitumoral activities. ${ }^{21,}{ }^{22}$ Schiff base derived fromaromatic aldehyde or ketones were capable of forming bidentate, tridentate, or tetradentate complexes with certain transition metal ions like $\mathrm{Cr}(\mathrm{III}), \mathrm{Co}(\mathrm{II}), \mathrm{Fe}(\mathrm{II}), \mathrm{Mn}(\mathrm{II}), \mathrm{Zn}(\mathrm{II}), \mathrm{Cd}(\mathrm{II})$, etc having many biological properties due to their electronic configuration, size, varied denticity, and steric reasons., ${ }^{3,4,23}$ During the past decades, Schiff base metal complexes of $\mathrm{Cr}(\mathrm{III}), \mathrm{Co}(\mathrm{II}), \mathrm{Cd}(\mathrm{II}, \mathrm{Zn}(\mathrm{II})$ ) obtained from 2- hydroxynaphthaldehyde showed a wide range of geometries which are octahedral, tetrahedral and distorted square pyramidal. ${ }^{24,25}$ Among the transition metal, Zinc, cadmium and cobalt have wide importance in biological process. ${ }^{2,5,26} \mathrm{Cd}(\mathrm{II})$ and Zinc(II)complexes of Schiff base have potential applications in fluorescence study and luminescence properties, due to electrons delocalization around the conjugated system of aromatic rings. ${ }^{9,23,27}$ Also,naphthaldehyde based Schiff base derivatives of $\mathrm{Co}(\mathrm{II})$ and $\mathrm{Cu}(\mathrm{II})$ complexes used as urease inhibitor and anticancer drugs. ${ }^{18,28}$ Recent reports have shown that cobalt(II) complexes with Schiff

Rasayan J. Chem., 13(3), 1685-1691(2020)

http://dx.doi.org/10.31788/RJC.2020.1335689 
RASĀYAN J. Chem.

Vol. 13 | No. 3 |1685-1691| July - September | 2020

base having aromatic $\mathrm{N}$ - substituent used as coordination network, polymers and metal-organic frameworks. ${ }^{29}$

In this paper, we synthesized a new asymmetrical mononuclear Schiff base metal complexes of $\mathrm{Cr}(\mathrm{III})$, $\mathrm{Co}(\mathrm{II}), \quad \mathrm{Zn}(\mathrm{II}), \quad$ and $\mathrm{Cd}(\mathrm{II}) \quad$ derived from ligand 3,3-((1E,1 $1 \mathrm{E})-((4-m e t h y l$ 1,2phenylene)bis(azanylylidene))bis(methanylylidene))bis(naphthalene-2-ol), which were prepared by the condensation of 2- hydroxy 1-naphthaldehyde and 3,4-diamino toluene (Scheme-1). All the complexes (1-4)and tetradentate Schiff base ligand were identified and characterized by spectral techniques using NMR, IR, ESR, UV-Visible, Mass spectra, Elemental analysis in continuation with magnetic moment methods. Furthermore, the antibacterial properties of the ligand and mononuclear complexes (1-4) were tested against bacteria E. coli, B. megaterium and P.aeruginosafor the determination of inhibition potential.

\section{Material and Methods}

\section{EXPERIMENTAL}

All A.R. grades chemicals and solvents were used. Elemental analysis data were recorded using a PerkinElmer CHN 2400 elemental analyzer. The UV/Visible spectra were recorded by Perkin-Elmer LAMBDA 25 spectrophotometer. Infra-Red spectra were recorded on a Thermo-fisher Nicolet iS5 FTIR spectrometer. ${ }^{1} \mathrm{HNMR}$ and ${ }^{13} \mathrm{CNMR}$ spectra were recorded using a Bruker AVANCE III $500 \mathrm{MHz}$ NMR (AV 500) spectrometer in DMSO-d $\mathrm{d}_{6}$. ESR spectra of the complexes were recorded at an EMX micro A200-9.5/12/S/W, BRUKNER BIOSPIN. Mass spectra of the ligand and metal complexes were recorded on a AB SCIEX Triple TOF 5600+ LCMS-MS spectrometer. Gouy method was used to determine the magnetic moment of metal complexes using $\mathrm{Hg}\left[\mathrm{Co}(\mathrm{SCN})_{4}\right]$, as calibrant at room temperature.

\section{Synthesis of Ligand (L) 3,3-((1E,1E)-((4-methyl-1,2-phenylene)bis(azanylylidene))bis (methanylylidene))bis(naphthalene-2-ol)}

An ethanolic solution of 2-hydroxy naphthaldehyde $(25 \mathrm{ml})(0.02398 \mathrm{~mol}, 4.130 \mathrm{~g})$ was added dropwise, over a stirred solution of 3,4- diamino toluene $(0.01195 \mathrm{~mol}, 1.460 \mathrm{~g})$ in warm ethanol $(45 \mathrm{ml})$. The reaction mixture was refluxed with stirring on oil bath at $70-80^{\circ} \mathrm{C}$ for $2-3 \mathrm{hrs}$. A yellow solid was filtered off, washed with ethanol, diethyl ether and dried. The obtained product was purified by recrystallization from DMF. Yield: $75 \%(4.20 \mathrm{gm})$, M.p. $220^{\circ} \mathrm{C}$. Anal. Calcd. For $\mathrm{C}_{29} \mathrm{H}_{22} \mathrm{~N}_{2} \mathrm{O}_{2}$ : C, 80.91; H, 5.15; N, 6.51; O, 7.43. Found: C, 80.78; H, 5.08; N,6.45; O,7.34. Selected FT-IR $\left(\mathrm{KBr}, \mathrm{cm}^{-1}\right)$ : 3328(O-H), 2918(C-H aromatic), $1619(\mathrm{C}=\mathrm{N}), 1291(\mathrm{C}-\mathrm{O}$ phenolic $) .{ }^{1} \mathrm{HNMR}(500 \mathrm{MHz}$, DMSO- $\left.\mathrm{d}_{6}, \mathrm{ppm}\right): \delta 2.34\left(\mathrm{~d}, \mathrm{CH}_{3}\right), 7.17-7.57(\mathrm{~m}, \mathrm{CH}$ aromatic),8.22-8.41(dd, $\mathrm{HC}=\mathrm{N}), 15.14-15.36(\mathrm{~s}, \mathrm{OH})$. ${ }^{13} \mathrm{CNMR} \quad\left(100.622 \mathrm{MHz}, \quad \mathrm{DMSO}-\mathrm{d}_{6}\right): \quad \delta_{\mathrm{c}} 21.23, \quad 118.86,119.29, \quad 122.23, \quad 127.46, \quad 133.23,137.60$, 139.93,168.63, 169.48. Mass spectrum(LC/MS,ESI):m/z 430.17, Found: 430.50[M] $]^{+}$

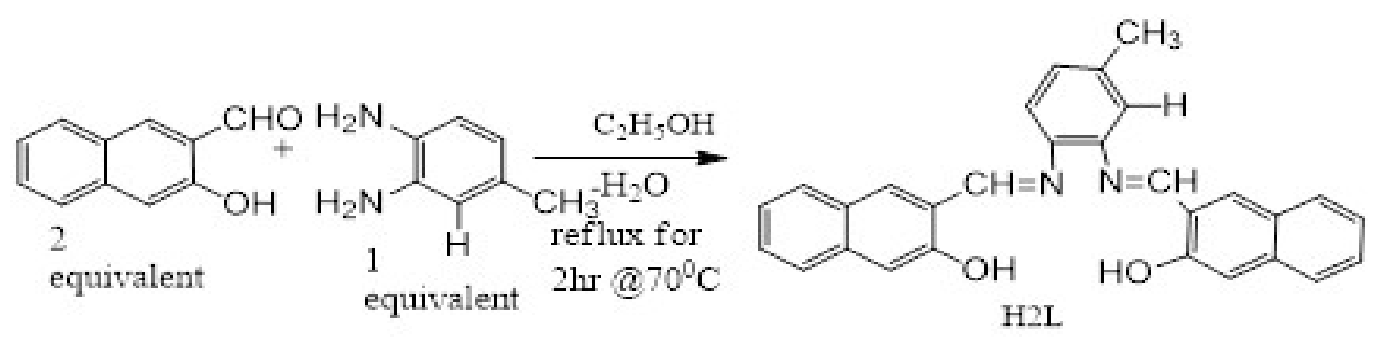

Scheme-1: Synthesis of Ligand

\section{General Procedure For the Synthesis of Metal Complexes}

Metal complexes(1 to4) were prepared with ligand (L), $0.230 \mathrm{~g}(0.0010 \mathrm{~mol})$ of $\mathrm{Cr}\left(\mathrm{CH}_{3} \mathrm{COO}\right)_{3}$, $0.250 \mathrm{~g}(0.0010 \mathrm{~mol}) \quad$ of $\mathrm{Co}\left(\mathrm{CH}_{3} \mathrm{COO}\right)_{2} \cdot 4 \mathrm{H}_{2} \mathrm{O}, 0.220 \mathrm{~g}(0.00095 \mathrm{~mol})$ of $\mathrm{Zn}\left(\mathrm{CH}_{3} \mathrm{COO}\right)_{2} \cdot 2 \mathrm{H}_{2} \mathrm{O}, 0.270 \mathrm{~g}($ $0.0010 \mathrm{~mol})$ of $\mathrm{Cd}\left(\mathrm{CH}_{3} \mathrm{COO}\right)_{2} 2 \mathrm{H}_{2} \mathrm{O}$, was dissolved in $20 \mathrm{ml}$ DMF separately, then added dropwise to a magnetically stirred solution of ligand $(\mathrm{L}) 0.430 \mathrm{~g}(0.0010 \mathrm{~mol})$ in $\mathrm{DMF}(20 \mathrm{ml})$ in $1: 1$ molar ratio(M:L). The resultant mixture was refluxed and stirred on an oil bath for $3 \mathrm{hrs}$ and then poured on to ice-cold water. 
RASĀYAN J. Chem.

Vol. 13 | No. 3 |1685-1691| July - September | 2020

Finally the brown, cherry red, yellow, and dark yellow colored solid for complexes (1-4) precipitated respectively. The solid colored compounds were filtered and washed with diethyl ether. The solid products were recrystallized in DMF/ DMSO and dried over $\mathrm{CaCl}_{2}$ in a vacuum.

\section{Complex 1}

Yield: 0.610 g(92.42\%), M.p. $310^{0} \mathrm{C}$, Anal. Calcd. for $\mathrm{C}_{31} \mathrm{H}_{24} \mathrm{~N}_{2} \mathrm{O}_{5} \mathrm{Cr}: \mathrm{C}, 66.90 ; \mathrm{H}, 4.35 ; \mathrm{N}, 5.03$; Cr, 9.34; O, 14.37. Found: C, 66.27; H, 4.10; N, 4.85; Cr, 9.13; O, 14.14. Selected FTIR spectrum $\left(\mathrm{KBr}, \mathrm{cm}^{-1}\right)$ : 3423(free $-\mathrm{OH}), 2920(\mathrm{C}-\mathrm{H}$ aromatic),1616(C=N), 1281(C-O, phenolic), 563(Cr-O), 500(Cr-N). Mass spectrum(LC/MS,ESI): m/z 556.11, Found: $558[\mathrm{M}+2]^{+}$.

\section{Complex 2}

Yield: 0.510 g(75\%), M.p. $290^{\circ}$ C, Anal. calcd. for $\mathrm{C}_{31} \mathrm{H}_{24} \mathrm{~N}_{2} \mathrm{O}_{5} \mathrm{Co}$ : C, 66.08; H, 4.29; N, 4.97; Co, 10.46 . Found, C, 65.76; H, 4.10; N, 4.56; Co, 10.23. Selected FTIR spectrum $\left(\mathrm{KBrcm}^{-1}\right): 3441($ free-OH$), 2921(\mathrm{C}-\mathrm{H}$ aromatic $), 1614(\mathrm{C}=\mathrm{N}), 1280(\mathrm{C}-\mathrm{O}$, phenolic $), 571(\mathrm{Co}-\mathrm{O}), 488(\mathrm{Co}-\mathrm{N})$. Mass spectrum $(\mathrm{LC} / \mathrm{MS}, \mathrm{ESI}): \mathrm{m} / \mathrm{z}$ 563.10, Found: $566[\mathrm{M}+3]^{+}$.

\section{Complex 3}

Yield: 0.510 g(78.46\%). M.p. $340^{\circ} \mathrm{C}$, Anal. calcd. for $\mathrm{C}_{29} \mathrm{H}_{21} \mathrm{~N}_{2} \mathrm{O}_{3} \mathrm{Zn}$ : C, 68.18; H, 4.14; N, 5.48; Zn, 12.80 . Found C, 68.10; H, 4.05; N, 5.23; Zn, 12.20. Selected FTIR spectrum $\left(\mathrm{KBr}, \mathrm{cm}^{-1}\right)$ : 3422(free OH), 2919(C$\mathrm{H}$, aromatic), $1616(\mathrm{C}=\mathrm{N}), 1244(\mathrm{C}-\mathrm{O}$, phenolic), 583(Zn-O), 546( $\mathrm{Zn}-\mathrm{N}) .{ }^{1} \mathrm{HNMR}$ spectrum $(500 \mathrm{MHz}$, DMSO- $\mathrm{d}_{6}, \quad$ ppm): $\delta \quad 2.49\left(\mathrm{~d}, \mathrm{CH}_{3}\right), \quad 7.22-7.77(\mathrm{~m}, \mathrm{C}-\mathrm{H}$ aromatic $), \quad 8.45-9.80(\mathrm{dd}, \mathrm{HC}=\mathrm{N}) .{ }^{13} \mathrm{CNMR}$ spectrum(DMSO-d $6,100.622 \mathrm{MHz}): \delta_{\mathrm{c}} 21.48,117.34,119.94,122.11,127.91,136.16,138.26,156.30$, 174.00. Mass spectrum (LC/MS, ESI): m/z 510.08, Found: $512.49[\mathrm{M}+2]^{+}$.

\section{Complex 4}

Yield:0.520g(74.28\%). M.p. $180^{\circ} \mathrm{C}$ Anal. calcd. for $\mathrm{C}_{29} \mathrm{H}_{21} \mathrm{~N}_{2} \mathrm{O}_{3} \mathrm{Cd}: \mathrm{C}, 64.40 ; \mathrm{H}, 3.73 ; \mathrm{N}, 5.18 ; \mathrm{Cd}, 20.78$.

Found, C, 64.23; H, 3.56; N, 5.09; Cd, 20.38. Selected FTIR spectrum $\left(\mathrm{KBr}, \mathrm{cm}^{-1}\right)$ : 3423(free $\left.\mathrm{OH}\right)$, 2920(C-H aromatic), $1618(\mathrm{C}=\mathrm{N}), \quad 1246\left(\mathrm{C}-\mathrm{O}, \quad\right.$ phenolic), 582(Cd-O), 532(Cd-N). ${ }^{1} \mathrm{HNMR}$ spectrum $\left(500 \mathrm{MHz}, \mathrm{DMSO}-\mathrm{d}_{6}, \mathrm{ppm}\right): \delta 2.50\left(\mathrm{~s}, \mathrm{CH}_{3}\right), 7.35(\mathrm{~m}, \mathrm{C}-\mathrm{H}$ aromatic $), 8.25-8.94(\mathrm{~m}, \mathrm{HC}=\mathrm{N}), 15.12-$ 15.35(s, free $-\mathrm{OH}) .{ }^{13} \mathrm{CNMR}\left(\mathrm{DMSO}-\mathrm{d}_{6}, 100.622 \mathrm{MHz}\right): \delta_{\mathrm{c}} 21.24,119.03,122.10,123.48,127.47,127.95$, 129.34, 136.66. Mass spectrum (LC/MS,ESI): m/z 559.06.
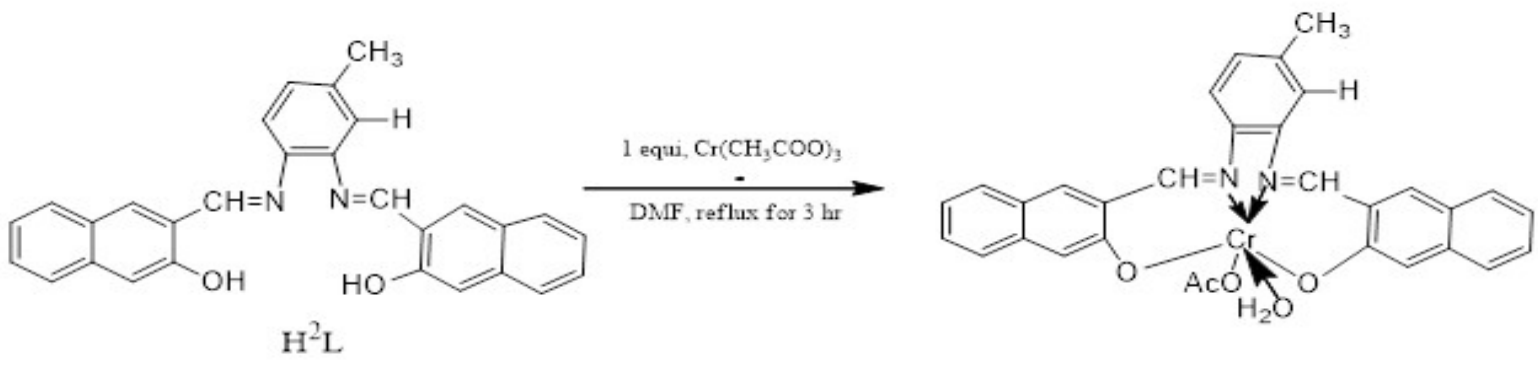

Scheme-2: Synthesis of Cr(III) Complex
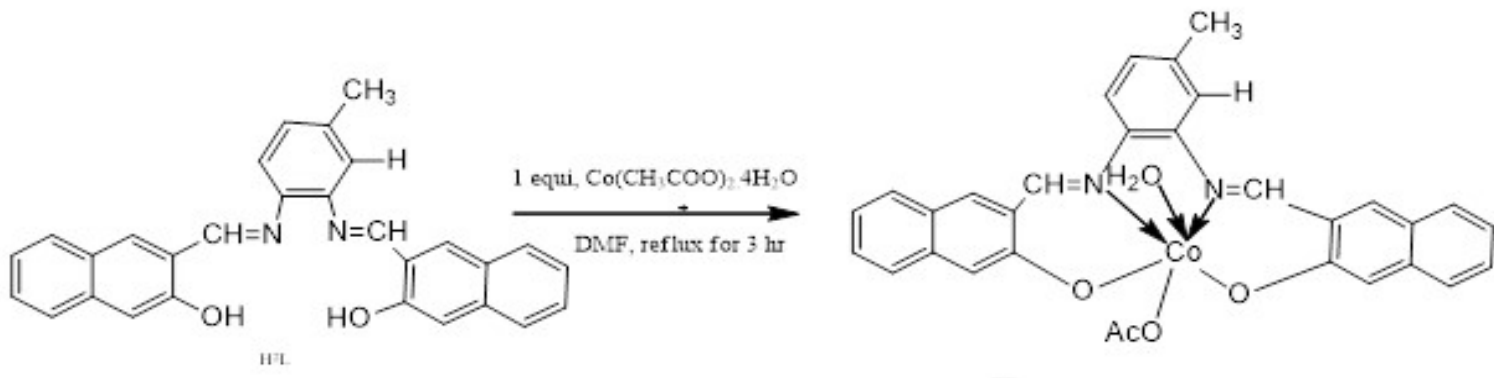

Scheme-3: Synthesis of Co(II) Complex 
RASĀYAN J. Chem.

Vol. 13 | No. 3 |1685-1691| July - September | 2020

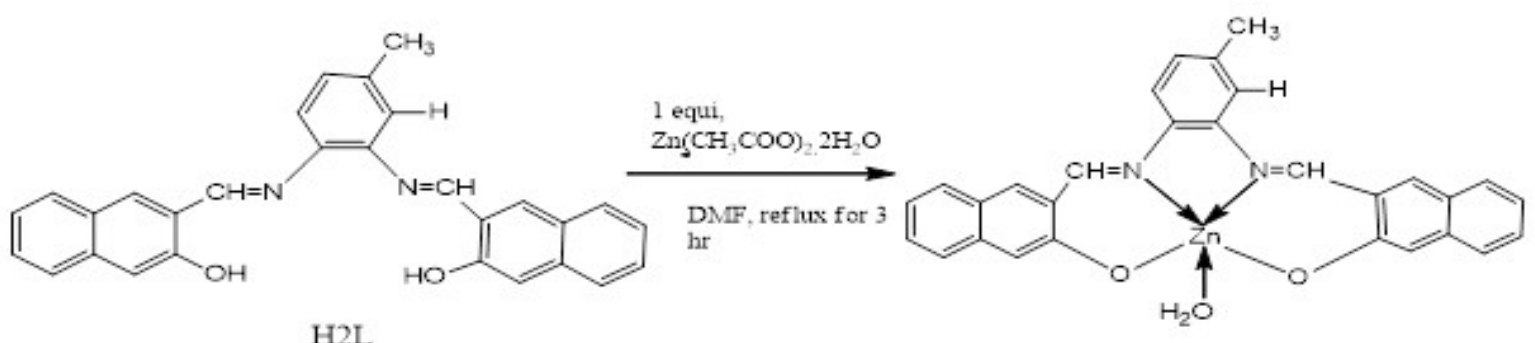

Scheme-4: Synthesis of Zn(II) Complex
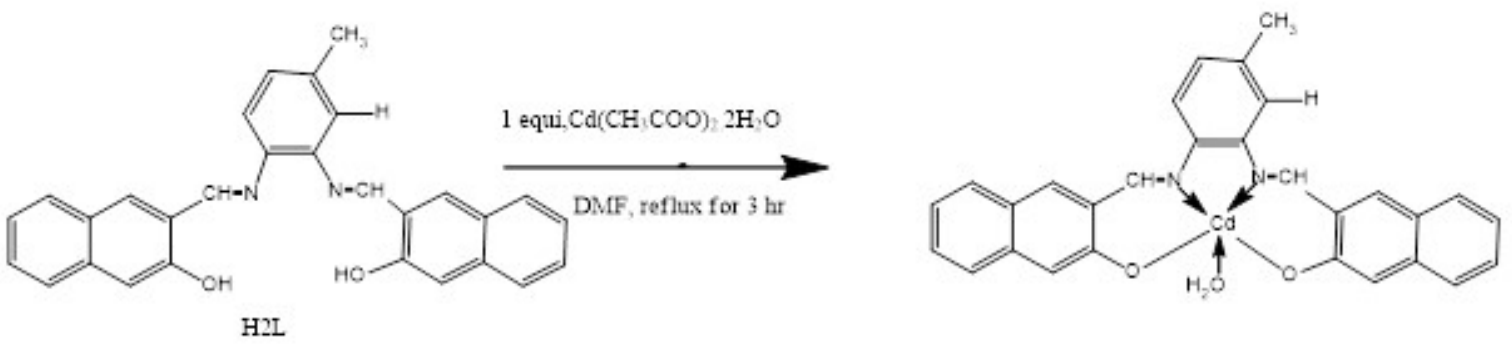

Scheme-5: Synthesis of Cd(II) Complex

\section{RESULTS AND DISCUSSION}

The reactions between metal acetates $(\mathrm{Cr}, \mathrm{Co}, \mathrm{Zn}, \mathrm{Cd})$ and ligand( $\mathrm{L})$ (Schemes-2 to 5) were carried out in molar ratio (1:1)and coloured compounds were obtained (1-4). The spectroscopic techniques such as FTIR, ${ }^{1} \mathrm{HNMR},{ }^{13} \mathrm{C}$ NMR, Mass spectra, EPR spectra and Elemental analysis were used, to verify the coordination of ligand with the metal ions. All compounds were stable at room temp. and were soluble in DMSO/ DMF.

\section{IR Spectra}

The FTIR spectra of ligand (L), exhibited medium intensity stretching band at $3328 \mathrm{~cm}^{-1}$ which was characteristic of phenolic $\mathrm{OH}$ group ${ }^{25}$. The $v(\mathrm{CH}=\mathrm{N})$ stretching band of the azomethine group appears at $1619 \mathrm{~cm}^{-1}$ for ligand, which were shifted to a lower frequency, assigned at $1616 \mathrm{~cm}^{-1}, 1614 \mathrm{~cm}^{-1}, 1616 \mathrm{~cm}^{-1}$ and $1618 \mathrm{~cm}^{-1}$ for complexes1,2,3 and 4 respectively. The shifting of these vibrational bands was due to the coordination of azomethine nitrogen atom with that of the metal ion. The phenolic C-O stretching band persists at $1291 \mathrm{~cm}^{-1}$ in Schiff base ligand whereas these bands were showed red shift at $1281 \mathrm{~cm}^{-1}, 1280 \mathrm{~cm}^{-}$ $1,1244 \mathrm{~cm}^{-1}$ and $1246 \mathrm{~cm}^{-1}$ in metal complexes $\mathbf{1 , 2 , 3}$ and 4 respectively. These results revealed that the metal ions were coordinated with oxygen atoms. ${ }^{31}$ Some new additional vibrational bands appeared in the range 583- $563 \mathrm{~cm}^{-1}$ and $546-488 \mathrm{~cm}^{-1}$ was assigned to $v(\mathrm{M}-\mathrm{O})$ and $v(\mathrm{M}-\mathrm{N})$ respectively. ${ }^{32}$ The spectra of complexes ( 1 to 4) exhibited stretching vibrational bands at $3423,3441,3442$ and $3423 \mathrm{~cm}^{-1}$, assigned to coordinated water molecules associated with the complexes ${ }^{25}$.

\section{UV/Visible Spectra}

The electronic spectra of Land metal complexes(1to4) were recorded in DMSO solution. All the complexes showed a blue shift in the spectra on comparing with ligand and some new bands also appeared in the spectra of metal complexes. The UV/visible spectra of ligand exhibited three sharp peak at $273 \mathrm{~nm}, 322 \mathrm{~nm}$ and $375 \mathrm{~nm}$, attributed to $\pi-\pi^{*}, \mathrm{n}-\pi^{*}$ and charge transfer transition respectively. These transitions were assigned to the aromatic ring and azomethine $(\mathrm{CH}=\mathrm{N})$ group respectively ${ }^{33}$.The $\mathrm{UV} /$ Visible spectra of $\mathrm{Cr}$ (III) complex(1) exhibit three absorption peaks at $267 \mathrm{~nm}, 311 \mathrm{~nm}$ and $475 \mathrm{~nm}$, which attributed to ${ }^{4} \mathrm{~A}_{2 \mathrm{~g}} \rightarrow{ }^{4} \mathrm{~T}_{1 \mathrm{~g}}(\mathrm{P}),{ }^{4} \mathrm{~A}_{2 \mathrm{~g}} \rightarrow{ }^{4} \mathrm{~T}_{1 \mathrm{~g}}(\mathrm{~F})$, and ${ }^{4} \mathrm{~A}_{2 \mathrm{~g}} \rightarrow{ }^{4} \mathrm{~T}_{2 \mathrm{~g}}(\mathrm{~F})$, transitions respectively. These bands aresimilartothe complex of octahedral geometry. The magnetic moment was found to be 4.25 B.M. due to 3 unpaired 
RASĀYAN J. Chem.

Vol. 13 | No. 3 |1685-1691| July - September | 2020

electrons. The absorption spectra of Co(II) complex(2) showed five peaks at $274 \mathrm{~nm}, 333 \mathrm{~nm}, 372 \mathrm{~nm}, 420 \mathrm{~nm}$ and $472 \mathrm{~nm}$, assigned to $\pi-\pi^{*}, \mathrm{n}-\pi^{*}$, MLCT and ${ }^{4} \mathrm{~T}_{1 \mathrm{~g}}(\mathrm{~F}) \rightarrow{ }^{4} \mathrm{~T}_{1 \mathrm{~g}}(\mathrm{P})$ and ${ }^{4} \mathrm{~T}_{1 \mathrm{~g}}(\mathrm{~F}) \rightarrow{ }^{4} \mathrm{~A}_{2 \mathrm{~g}}(\mathrm{~F})$ transition respectively. These bands are also similar to six coordinated complexes which are compatible with octahedral geometry. The magnetic moment was found to be 5.34 B.M. at room temperature. The $\mathrm{Zn}$ (II) complex(3) exhibits four absorption peaks at $267 \mathrm{~nm}, 332 \mathrm{~nm}, 415 \mathrm{~nm}$ and $466 \mathrm{~nm}$ respectively, which are assigned to $\pi-\pi^{*}, \mathrm{n}-\pi^{*}$, MLCT transition respectively and suggesting a distorted square pyramidal geometry. The Cd(II)complex(4) exhibit four absorption peaks at $267 \mathrm{~nm}, 319 \mathrm{~nm}, 369 \mathrm{~nm}$ and $447 \mathrm{~nm}$ respectively, which is assigned to $\pi-\pi^{*}, \mathrm{n}-\pi^{*}, \mathrm{n}-\pi^{*}$, and MLCT transitions respectively, which are similar with distorted square pyramidal geometry. Complexes $\mathbf{3}$ and $\mathbf{4}$ are diamagnetic. ${ }^{2,4,33}$

\section{NMR Spectra}

The ${ }^{1} \mathrm{H}$ NMR spectra of the ligand(L) and complexes 3 and $\mathbf{4}$ were recorded in DMSO- $\mathrm{d}_{6}$ solvent using TMS as standard. The NMR spectra also supported the formation of complexes. The signals at $\delta 8.22-8.41(\mathrm{dd})$ were consistent with azomethine protons for ligand(L). The medium intensity peak at $\delta 2.34(\mathrm{~d})$ was observed for ligand, assigned to methyl protons. The NMR spectra of ligand showed two sharp signals at $\delta 15.14(\mathrm{~s})$ and $\delta 15.36(\mathrm{~s})$ were assigned to the phenolic -OH protons, these peaks were absent in complex (3) which represents the deprotonation and complexation with $\mathrm{Zn}(\mathrm{II})$ metal ion. ${ }^{26},{ }^{27} \mathrm{Complex} \mathbf{3}$ and $\mathbf{4}$ exhibits signals at $\delta 8.45(\mathrm{dd}), \delta 8.25(\mathrm{~m})$ respectively, which is assigned to $\mathrm{HC}=\mathrm{N}$ protons. Signals in the region $\delta 7.17$ $7.57(\mathrm{~m})$ were due to aromatic protons for ligand, which were shifted to $\delta 7.22-7.77$ and $\delta 7.35$ in the complexes3 and 4 respectively. The proton decoupled ${ }^{13} \mathrm{CNMR}$ spectra of the ligand showed a signal at $21.23 \mathrm{ppm}, 133.23-139.93 \mathrm{ppm}, 168.63-169.48 \mathrm{ppm}$ due to $-\mathrm{CH}_{3}$ carbon, aromatic ring of Schiff base and characteristic azomethine carbon atom respectively. The metal complexes $\mathbf{3}$ and $\mathbf{4}$ exhibit signals at $21.48 \mathrm{ppm}$ and $21.24 \mathrm{ppm}$ respectively due to $-\mathrm{CH}_{3}$ carbon atoms. The azomethine carbon peak observed at $156.30 \mathrm{ppm}$ for complex 3 .

\section{Mass Spectra}

The molecular ion peak of ligand and its complexes (1-4), was observed at $\mathrm{m} / \mathrm{z} 430.50[\mathrm{M}]^{+}, 558[\mathrm{M}+2]^{+}$, $566[\mathrm{M}+3]^{+}, 512.49[\mathrm{M}+2]^{+}, 559.06[\mathrm{M}]^{+}$respectively, which corresponds to their molecular formula and formula weight. Also of molecular ion peak, the ligand and its complexes (1 to 4) exhibited some additional peaks due to fragmentation, which arise from the thermal cleavage of the complexes. All these results suggest the stability of fragments and are good agreement with the proposed formulae of the ligand and its metal complexes.

\section{Antibacterial Activity}

The bacterial strains were obtained from Lala Lajpat Rai Memorial Medical College, Meerut. The tetradentate ligand and its metal complexes(1 to 4) were studied for their in-vitro antibacterial activity against $E$. coli, B. megaterium and $P$. aeruginosa bacterial strains by agar diffusion method. In this method, a solution of ligand and metal complexes were spread over agar plates seeded with tested bacterial strains. The agar plates were used for incubation at $35^{\circ} \mathrm{C}$ for 2-3 days. The antibiotic gentamicin was used as a standard drug against bacterial strains. The bacteriacidal activity was resolved by calculating the diameter of the inhibition zone. ${ }^{19}$, 33 These results showed that complexes (1-4) showed significant activity as compared to the ligand.

\section{CONCLUSION}

The ligand (L)was synthesized and further used for the preparation of $\mathrm{Cr}(\mathrm{III}), \mathrm{Co}(\mathrm{II}), \mathrm{Zn}$ (II), and $\mathrm{Cd}(\mathrm{II})$ complexes. The spectral data indicate that the metal complexes (1-4)were hexa and pentacoordinated with tetradentate ligand and hydroxyl group. Thus exhibit octahedral and distorted square pyramidal geometry respectively. All the complexes(1-4) were tested against the bacteria E. coli, B. megaterium and $P$. aeruginosa were investigated. The Co (II) complex showed higher activity against these bacteria.

\section{ACKNOWLEDGEMENT}

Authors are also thankful to Head, Department of Chemistry, DDU Gorakhpur University, Gorakhpur. Authors are also thankful to SAIF, Department of Chemistry, University of Delhi, ACBR, New Delhi for providing spectral facilities and Head, Chemistry Dept., MCM and Principal, Meerut College, Meerut for encouragement and providing necessary facilities. 
RASĀYAN J. Chem.

Vol. 13 | No. 3 |1685-1691| July - September | 2020

\section{REFERENCES}

1. D. Cincic and B. Kaitner, CrystEngComm, 13(13),4351(2011), DOI:10.1039/C1CE90016A

2. A. Majumder, G. M. Rosair, A. Mallick, N. Chattopadhyay and S. Mitra, Polyhedron, 25(8), 1753(2006), DOI:10.2016/j.poly.2005.11.029

3. H. Keypour, A. Shooshtari, M. Rezaeivala, F. O. Kup and H. A. Rudbari, Polyhedron, 97, 75(2015), DOI:10.1016/j.poly.2015.02.029

4. B. Kołodziej, M. Morawiak, W. Schilf and B. Kamieński, Journal of Molecular Structure,1184, 207(2019), DOI:10.1016/j.molstruc.2019.02.027

5. A. Vlad, M. Avadanei, S. Shova, M. Cazacu and M.-F. Zaltariov, Polyhedron, 146, 129 (2018), DOI:10.1016/j.poly.2018.02.029

6. W. Xu, W. Wang, J. Li, Q. Wu, Y. Zhao, H. Hou and Y. Song, Dyes and Pigments, 160, 1(2019), DOI:10.1016/j.dyepig.2018.07.046

7. Z. Bouhidel, A. Cherouana, P. Durand, A. Doudouh, F. Morini, B. Guillot and S.Dahaoui, InorganicaChimica Acta, 482, 34(2018), DOI:10.1016/j.ica.2018.05.028

8. B. Iftikhar, K. Javed, M. S. U. Khan, Z. Akhter, B. Mirza and V. Mckee, Journal of Molecular Structure, 1155, 337(2018), DOI:10.1016/j.molstruc.2017.11.022

9. G.Alpaslan, B. Boyacioglub, N. Demirc, Y. Tümerd, G. Yapare, N. Yıldırım, M. Yıldız and H. Ünverh, Journal of Molecular Structure, 1180, 170(2019), DOI:10.1016/j.molstruc.2018.11.065

10. N.P. Singh, U. Agarwal, A. Kumar and K. Kumar, Asian Journal of Chemistry, 32(5), 1091(2020), DOI: 10.14233/ajchem.2020.22544

11. S. Basak,S. Sen, C. Marschner, J. Baumgartner,S. R. Batten, D. R. Turner and S. Mitra, Polyhedron, 27(4), 1193(2017), DOI:10.1016/j.poly.2007.12.005

12. O. V. Nesterova, D. S. Nesterov, A. Krogul-Sobczak, M. F. C. G. da Silva and A. J. Pombeiro, Journal of Molecular Catalysis A: Chemical,426, 506(2017), DOI:10.1016/j.molcata.2016.09.005

13. M. A. Ayoub, E. H. Abd-Elnasser, M. A. Ahmed and M. G. Rizk, European Journal of Chemistry,8(1), 85(2017), DOI:10.5155/eurjchem.8.1.85-95.1513

14. A. Ourari, W. Derafa, Wassila and D. Aggoun, RSC Advances, 5(101), 82894(2015), DOI: $10.1039 /$ C5RA10819E

15. G. Puthilibai and S. Vasudhevan, Rasayan Journal of Chemistry,12(2), 855(2019), DOI: $10.31788 /$ RJC.2019.1225184

16. K. Jana, T. Maity, T. S. Mahapatra, P. K. D. Mohapatra, S. C. Debnath, S. Das, Somnath, M, Hossain and B. C. Samanta, Transition Metal Chemistry.,42(1), 69(2017), DOI:10.1007/s11243-016-0108-6

17. E. Yousif, A. Majeed, K. Al-Sammarrae, N. Salih, J. Salimon and B. Abdullah Arabian Journal of Chemistry, 10, S1639(2017), DOI:10.1016/j.arabjc.2013.06.006

18. W. Jia, H. Zhang, T. Zhang and S. Ling, Inorganic Chemistry Communications., 66, 15(2016), DOI: j.inoche.2016.02.001

19. C. Mari, V. Pierroz, S. Ferrari, G. Gasser, Chemical Science, 6(5), 2660(2015), DOI: $10.1039 / \mathrm{c} 4 \mathrm{sc} 03759 \mathrm{f}$

20. J. Vančo, Z. Šindelář, Z. Dvořák, Z. Trávníček, Journal of Inorganic Biochemistry.,142, 92(2015), DOI: $10.1016 /$ j.jinorgbio.2014.10.002

21. Y-T., G. Lian, D. Yin and B. Su, SpectrochimicaActa Part A: Molecular and Biomolecular Spectroscopy, 100, 131(2013), DOI:10.1016/j.saa.2012.03.049

22. D. Majumdar, S. Das, J. K. Biswas and M. Mondal, Journal of Molecular Structure, 1134, 617(2017), DOI: $10.2016 /$ j.molstruc.2017.01.002

23. D. Cincic and B. Kaitner, CrystEngComm, 13(13), 4351(2011), DOI:10.1039/C0CE00421A

24. H. Yilmaz and O. Andac, Journal of Chemical Sciences, 130(4), 32(2014), DOI:10.1007/s12039-0181436-1

25. L.L. Wen, Z.D. Lu, J.G. Lin, Z.F. Tian, H.Z. Zhu and Q.J. Meng, Crystal Growth \&Design,7(1), 93(2007), DOI:10.1021/cg0604982 
RASĀYAN J. Chem.

Vol. 13 | No. 3 |1685-1691| July - September | 2020

26. L. W. Xue, Q. L. Pen, P. P. Wang and H. Zhang Acta Chimica Slovenica, 66(3), 694(2019), DOI: $10.17344 /$ acsi.2019.5151

27. S. S. Kolate, G. P. Waghulde and C. J. Patil Rasayan Journal of Chemistry, 13(2), 1008(2020), DOI: 10.31788/RJC.2020.1325606

28. S. J. Lee and S. W. Lee, Polyhedron, 159, 259(2019), DOI:10.1016/j.poly.2018.12.003

29. X. Jiang, L. Sheng, C. and Song, N. Du, H. Xu, Z. Liu and S. Chen, New Journal of Chemistry, 40(4), 3520(2016), DOI: 10.1039/C5NJ01601K

30. O. M. I. Adly, M. Shebl, H. F. El-Shafiy, S. M.E. Khalil, A. Taha, Moh. A.N. Mahdi, Journal of Molecular Structure, 1150, 507 (2017), DOI:10.1016/j.molstruc.2017.08.009

31. J. Song, M. Wang, X. Zhou and H. Xiang, Chemistry -A European Journal,24(28), 7128(2018), DOI: $10.1002 /$ chem. 201801414

32. A. G. Imer, R. H. B. Syan, M. Gülcan, Y. S. Ocak and A. Tombak Journal of Materials Science: Materials in Electronics, 29(2), 898(2018), DOI:10.1007/s10854-017-7986-Z

33. V. S. Mironov, T. A. Bazhenova, Yu. V. Manakin, K. A. Lyssenko, A. D. Talantsev and E. B. Yagubskii, Dalton Transactions, 46(41), 14083(2017), DOI:10.1039/C7DT02912H

[RJC-5689/2020] 